\title{
PENERAPAN SIX SIGMA UNTUK MENGANALISA PEMANFAATAN TEKNOLOGI INFORMASI DAN KOMUNIKASI PADA UKM BATIK TULIS LASEM
}

\author{
A. Aviv Mahmudi \\ Program Studi Manajemen-S1 STIE YPPI Rembang \\ Jl. Raya Rembang-Pamotan KM. 4 Rembang \\ Email: viva.althaf@gmail.com
}

\begin{abstract}
ABSTRAK
UKM Batik Tulis Lasem merupakan salah satu produk unggulan Kabupaten Rembang. Pemanfaatan teknologi pada UKM Batik Tulis Lasem diantaranya kurangnya pemanfaatan teknologi informasi dan komunikasi yang menunjang proses produksi maupun pemasaran berbasis internet/e-commerce. Untuk itu diperkukan peningkatan layanan pelanggan melalui pemanfaatan TIK khususnya media online untuk mendukung layanan pada pelanggan, meningkatkan kualitas serta memperbaiki kekurangan layanan yang ada. Analisis data dilakukan dengan diawali melakukan uji validitas dan reliabilitas, melakukan uji normal multivariate dan stabilitas data, serta melakukan tahapan Six Sigma. Hasil penlitian menunjukkan bahwa dari pengidentifikasian faktor-faktor yang telah dilakukan pada maka dapat diketahui yang menyebabkan beberapa perusahaan tidak memanfaatkan teknologi informasi yaitu UKM yang belum menggunakan perangkat komputer di UKM, tingginya biaya koneksi internet, tidak memiliki tenaga ahli bidang TIK, tidak memiliki strategi bisnis melalui internet, kemampuan SDM pemilik dalam TI rendah, kurang bermanfaat bagi perusahaan, kendala ketersedian koneksi internet (ISP).
\end{abstract}

Kata kunci: Batik Tulis, Kualitas Layanan, Six Sigma,

\begin{abstract}
Batik Tulis Lasem SME is one of the superior products in Rembang Regency. The use of technology in Batik Tulis Lasem SME includes the lack of utilization of information and communication technology that support production and internet/e-commerce for marketing For this reasin, it is necessary to improve customer service through the use of Information Communication Technology (ICT) especially online media to support services to customers, improve quality and improve existing service deficiencies. Data analysis was carried out by beginning with validity and reliability test, conducting normal multivariate and data stability tests, and performing Six Sigma stages.The results of the study indicate that from the identification of the factors that have been carried out, it can be seen that causes some companies do not utilize information technology such as SMEs that have not used computer equipment, high cost of internet connections, do not have ICT experts, do not have a business strategy through the internet, the ability of human resource owners in IT is still low less useful for companies, constraints of internet connection availability (ISP).
\end{abstract}

Keywords : Batik Tulis Lasem, Service Quality, Six Sigma 


\section{PENDAHULUAN}

Kemajuan Teknologi Informasi memungkinkan kegiatan bisnis perusahaan memiliki keunggulan kompetitif, serta mampu menyediakan manajemen interdependensi yang efektif [1]. Pengadopsian TIK bagi perusahaan terutama usaha kecil dan menengah (UKM) memiliki efek positif pada produktivitas baik secara langsung maupun tidak langsung dan memiliki potensi besar untuk mendukung pembangunan berkelanjutan [2]. Penerapan Teknologi Informasi dan Komunikasi (TIK) jika digunakan dengan tepat pada UKM terbukti mampu meningkatkan kinerja secara keseluruhan, keuangan dan operasional UKM melalui kegiatan pemasaran, komunikasi, jaringan dan sumber daya perencanaan [3].

UKM Batik Tulis Lasem merupakan salah satu produk unggulan Kabupaten Rembang [4]. Hasil penelitian [5] terdapat sejumlah permasalahan yang dihadapi batik tulis Lasem yaitu: pengelolaan usaha masih sangat sederhana, rata-rata SDM memiliki tingkat pendidikan yang rendah, belum memiliki kemampuan yang baik dalam memasarkan produk yang dihasilkan, keterbatasan finansial, keterbatasan akses bahan baku dan keterbatasan teknologi. Pemanfaatan teknologi pada UKM Batik Tulis Lasem diantaranya kurangnya pemanfaatan teknologi informasi dan komunikasi yang menunjang proses produksi maupun pemasaran berbasis internet/ecommerce. Masyarakat saat ini semakin banyak memanfaatkan internet sebagai media komunikasi dan informasi.

Pesatnya perkembangan internet saat ini belum dimanfaatkan secara optimal oleh UKM Batik Tulis Lasem, hal ini tercermin masih belum banyaknya UKM yang memanfaatkan internet sebagai salah satu media pemasaran serta penunjang kegiatan pekerjaan lainnya. Untuk itu diperkukan peningkatan layanan pelanggan melalui pemanfaatan TIK khususnya media online untuk mendukung layanan pada pelanggan, meningkatkan kualitas serta memperbaiki kekurangan layanan yang ada. Adapun salah satu metode yang mampu meningkatkan kualitas layanan adalah Six Sigma, yaitu sebuah metodologi yang terstruktur yang berfokus pada perbaikan proses dengan mengurangi variasi proses dan mengurangi cacat secara intensif.

Six Sigma telah diadopsi oleh banyak organisasi di seluruh dunia, adapun penerapan Six Sigma terutama dalam industri jasa diantaranya perbankan dan jasa keuangan, perawatan kesehatan, konstruksi, pasokan manajemen rantai, akuntansi, hubungan pelanggan, utilitas publik, material pengadaan, pendidikan, perpustakaan, pemrosesan pemesanan, industri penerbangan, keselamatan dan bahkan pemerintah dan nirlaba [6].

Beberapa penelitian yang menerapkan metodologi six sigma dan servqual dengan tujuan meningkatkan kinerja pelayanan publik Kantor Kecamatan Kedungbanteng. Metode Six Sigma dengan Fase DMAIC (Define, Measure, Analyze, Improve, Control). Dimensi Servqual dan Six Sigma dapat diterapkan untuk meningkatkan kualitas pelayanan publik, selain itu diperlukan adanya perbaikan-perbaikan terhadap proses pelayanan dan juga pengontrolan agar proses berjalan lebih baik lagi dan kualitas kinerja pelayanan publik dapat lebih ditingkatkan [7]. Metode six sigma juga digunkaan untuk meningkatkan kualitas klongsong pada industri senjata. Konsep Six Sigma digunakan untuk menemukan dan mengurangi faktor-faktor yang menyebabkan kecacatan dan kesalahan sehingga dapat meningkatkan kualitas untuk mencegah tingkat kegagalan nol. Pada tahap Definisikan DMAIC adalah mendefinisikan CTQ (Critical-To-Quality) serta alam fase Analisis DMAIC penyebab cacat dianalisis melalui diagram Ishikawa. Memperbaiki fase DMAIC persiapan perbaikan yang diusulkan didasarkan pada prioritas menggunakan FMEA [8]. Dengan menggunakan metode Six Sigma ini dapat mengidentifikasi terhadap faktor-faktor yang menyebabkan UKM Batik Tulis Lasem tidak menggunakan TIK, mengukur dan mendapatkan solusi dalam menangani permasalahan terhadap faktor-faktor yang menyebabkan UKM Batik Tulis Lasem tidak menggunakan TIK.

\section{TINJAUAN PUSTAKA}

Usaha Mikro, Kecil dan Menengah (UMKM) atau saat ini disebut dengan UKM merupakan sebuah usaha ekonomi produktif yang dijalankan perseorangan maupun badan usaha yang memiliki kekayaan bersih dan hasil penjualan tertentu, sehingga dimasukkan dalam kriteria UMKM [9]. UMKM merupakan kekuatan strategis dan penting dalam pembangunan ekonomi Indonesia. UMKM memiliki peran penting dalam penyediaan lapangan kerja, memberikan kontribusi signifikan terhadap pertumbuhan ekonomi dan memeratakan pendapatan [10].

Six sigma merupakan suatu falsafah dan aktivitas perbaikan mutu berkelanjutan menuju zero defect. Dengan six sigma, cacat dan kesalahan yang terjadi atas produk sebesar 3,4 unit per sejuta keluaran. Six sigma mewakili enam simpangan baku (Sigma berasal dari huruf Yunani yang digunakan untuk menyatakan simpangan baku dalam statistik atas rata-rata dari data). Metodologi Six Sigma menyediakan peralatan dan teknik untuk meningkatkan kinerja dan mengurangi cacat dalam proses manapun yang kita laksanakan. Six sigma dimulai penerapannya pada Motorola, yaitu pada divisi pabrikasi, tempat diproduksi berjuta-juta komponen dengan menggunakan proses sama yang dilaksanakan berulangkali. Dengan cepat, Six Sigma berhasil meningkatkan mutu keluaran sehingga diterapkan pula pada divisi selain divisi pabrikasi (Aboelmaged, 2010).

Six Sigma telah diadopsi oleh banyak organisasi di seluruh dunia, adapun penerapan Six Sigma terutama dalam industri jasa diantaranya perbankan dan jasa keuangan, perawatan kesehatan, konstruksi, pasokan manajemen rantai, akuntansi, hubungan pelanggan, utilitas publik, material pengadaan, pendidikan, perpustakaan, pemrosesan pemesanan, industri penerbangan, keselamatan dan bahkan pemerintah dan nirlaba [6].

Tahapan utama Six Sigma: 
Jurnal Ilmiah Ilmu Komputer Vol. 6, No. 1, Bulan April 2020 Fakultas Ilmu Komputer

Universitas AL Asyariah Mandar

1. Fase atau tahapan DMAIC adalah sebagai berikut:

Define (Definisikan) - Proyek dimulai dengan membuat piagam tim untuk mengidentifikasi anggota tim, memilih proses yang akan ditingkatkan oleh tim dan secara jelas menentukan tujuan proyek. Tim proyek kemudian akan mengidentifikasi CTQ untuk membantu mengukur dampak masalah pada pelanggan. Fase ini selesai ketika tim membuat peta proses yang mencakup input dan output proses.

Measure (mengukur) - Fase ini termasuk membuat dan melaksanakan rencana pengumpulan data yang menyediakan data yang dapat diandalkan dan signifikan. Data menunjukkan bagaimana proses tersebut berjalan dan membantu mengidentifikasi penjahat dalam narasi Six Sigma - varians.

Analysis (analisis) - Setelah kinerja proses dikuantifikasi, tahap analisis membantu mengidentifikasi kemungkinan penyebab masalah.

Improve (tingkatkan) - Setelah akar masalah menjadi terungkap, fase perbaikan berfokus untuk menemukan solusi permanen untuk masalah tersebut. Di sinilah kreativitas tim proyek berperan dalam menemukan jawaban untuk masalah proses yang sudah berjalan lama.

Control (kontrol) - Pada fase ini, tim proyek mendokumentasikan solusi baru yang telah dibuat sehingga dapat diteruskan kepada pemilik proses. Adapun aktivitas kontrol yang digunkanan dalam program Six Sigma, adalah:

a. Mendokumentasikan hasil peningkatan kualitas dan menstandarisasikan proyek kinerja ke dalam prosedur kerja agar dijadikan sebagai standar pedoman kinerja.

b. Menyebarluaskan hasil peningkatan kualitas dan praktek terbaik yang telah distandarisasikan ke dalam prosedur kerja seluruh organisasi.

Selanjutnya dilakukan tahapan perhitungan six sigma sebagai berikut:

a. Menghitung kemampuan proses dan capability process;

$$
\begin{array}{ll}
\mathrm{Cp}=\frac{U C L-L C L}{6 \sigma} \text { dan Cpk }=\left(\frac{U C L-\mu}{3 \sigma}, \frac{\mu-L C L}{3 \sigma}\right) \\
\begin{array}{ll}
\text { Dimana; } & \\
\text { Cp dan Cpk }= & \begin{array}{l}
\text { Capability Process Index (indeks } \\
\text { kemampuan proses) }
\end{array} \\
\mathrm{UCL} & \text { Upper Control Limit (Batas Pengendali } \\
& \text { Atas) } \\
\mathrm{LCL} & \text { Lower Control Limit (Batas Pengendali } \\
& \text { Bawah) } \\
\sigma & =\text { Simpangan baku }
\end{array}
\end{array}
$$

b. Menghitung DPMO (Defect Per Million Opportunity); yaitu tingkat ketidaksesuaian dari satu juta produk atau jasa.

Nilai Sigma $=(1-$ tingkat kepuasan $) \times 1.000 .000$

c. Menghitung Tingkat Sigma.

Nilai sigma $=$ normsinv $\left(1-\frac{D P M O}{1000000}\right)+1,5$

d. Diagram Pareto

Diagram pareto digunakan sebagai metode untuk menganalisis kesalahan, masalah arat cacat untuk membantu penyelesaian masalah.

e. Diagram Fishbone
(P) ISSN 2442-451X

(O) ISSN 2503-3832

Diagram fishbone digunakan untuk mengetahui letakletak masalah kualitas, serta untuk menyajikan penyebab suatu masalah secara grafis.

\section{METODE YANG DIUSULKAN}

Jenis data yang dilakukan dalam penelitian ini adalah data kuantitatif yang diperoleh dari data perusahaan (UKM Batik Tulis Lasem) dan penjelasan dari narasumber. Adapun sumber data penelitian ini, sebagai berikut:

1. Data Primer, yang diperoleh langsung dari pemilik UKM Batik Tulis Lasem, melalui wawancara serta kuesioner. Teknik pengambilan sampel penelitian ini menggunakan purposive sampling yaitu pemilihan responden dengan kriteria UKM Batik Tulis dengan skala kecil, menengah dan besar, pengambilan ukuran besar kecilnya perusahaan dilihat dari jumlah karyawan yang terlibat dalam proses produksi Batik Tulis lasem.

2. Data sekunder, yaitu data yang diperoleh dari sumber tertulis yaitu sumber buku dan artikel ilmiah (jurnal penelitian dan prosiding).

Bagan alir penelitian merupakan suatu bagan yang menggambarkan garis besar penelitian yang akan dilakukan sebagaimana Gambar 1.

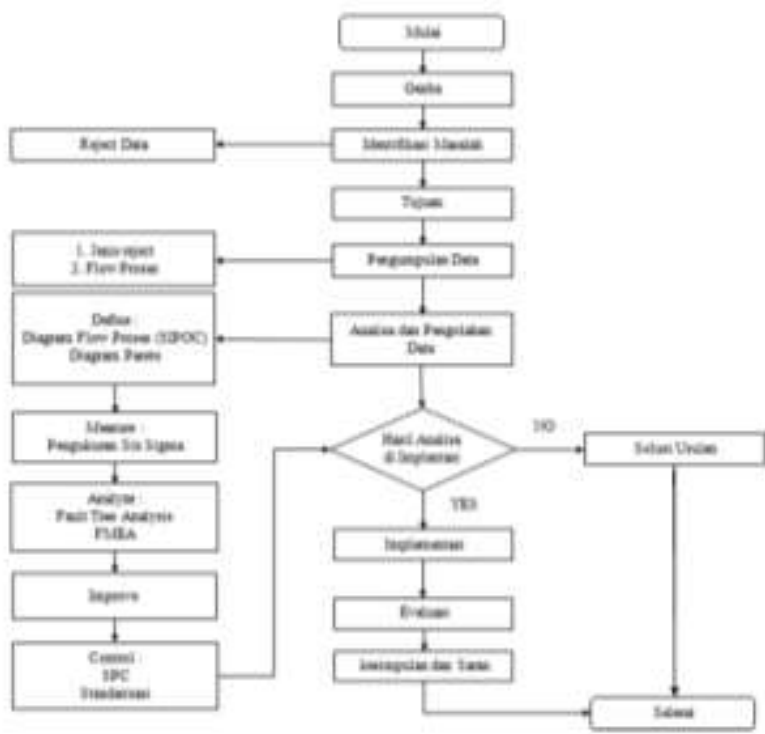

Gambar 1. Bagan Air Penelitian

Analisis data dilakukan dengan diawali melakukan uji validitas dan reliabilitas dari jawaban responden serta melakukan uji normal multivariate dan stabilitas data, setelah terpenuhi maka tahapan berikutnya Six Sigma.

\section{HASIL PENELITIAN}

Analisis data dilakukan dengan tahapan berikut:

1. Define (Tahap Pendefinisian)

Fase define adalah hal yang pertama dilakukan dalam menggunakan metode Six Sigma. Pada fase ini hal pertama yang dilakukan adalah mengidentifikasikan faktor-faktor yang dianggap penting oleh konsumen Critical to Quality (CTQ). Berdasarkan hasil survey yang telah dilakukan terhadap 40 responden dari pada UKM 
Jurnal Ilmiah Ilmu Komputer Vol. 6, No. 1, Bulan April 2020 Fakultas Ilmu Komputer

Universitas AL Asyariah Mandar

Batik Tulis Lasem, terdapat 32 responden telah memanfaatkan teknologi informasi dan komunikasi sebagai sarana komunikasi dan bisnis, dan 8 responden tidak memanfaatkan teknologi informasi dan komunikasi. Berdasarkan keterangan tersebut dapat diketahui bahwa teknologi informasi dan komunikasi bukanlah sesuatu yang baru bagi UKM batik tulis Lasem. Sebagian besar UKM telah menggunakan teknologi informasi dan komunikasi sebagai media komunikasi, promosi dan untuk mendapatkan informasi yang dibutuhkan. Sedangkan bagi UKM batik tulis Lasem yang tidak menggunakan teknologi informasi dan komunikasi bukanlah dikarenakan mereka tidak menyadari akan kehadiran teknologi informasi dan komunikasi serta manfaatnya, namun dikarenakan beberapa faktor, antara lain:

a. UKM yang belum menggunakaan perangkat komputer di UKM

Sebagian besar dari responden belum menggunakan perangkat komputer dalam membantu pengelolaan usahanya. Pemilik UKM hanya menggunakan perangkat handphone/gadget untuk membantu menjunjang pemasaran dan terbatas pada pemanfaatan media sosial.

b. Tidak memiliki tenaga ahli bidang TIK

Beberapa responden menyatakan bahwa UKM mereka tidak memiliki tenaga ahli bidang TIK, sedangkan untuk menggaji tenaga ahli dari luar membutuhkan biaya yang relatif mahal.

c. Kemampuan SDM pemilik dalam TI Rendah Faktor pendidikan, kurangnya pelatihan bagi pemilik UKM menjadikan kemampuan pemamahaman teknologi informasi menjadi rendah.

d. Tidak memiliki strategi bisnis melalui internet Bisnis melalui internet di Indonesia dalam hal ini adalah e-Commerce belumlah mem"booming". Hal ini dikarenakan masih banyak UKM yang belum memiliki strategis bisnis dalam membangun $e$ Commerce. Strategi e-Commerce yang dimaksud antara lain:

a. Menentukan model bisnis yang akan diterapkan di dalam e-Commerce.

b. Mendefinisikan segmen pasar dan tipe pelanggan yang akan menjadi target.

c. Menyusun kebijakan atau peraturan pembelian dan pembayaran melalui internet bagi pelanggan.

e. Kurang bermanfaat bagi perusahaan

Banyak responden menyatakan bahwa UKM mereka belum membutuhkan teknologi informasi dan komunikasi sebagai media komunikasi, promosi, maupun mencari informasi. Hal ini dikarenakan minimnya informasi yang mereka dapatkan mengenai manfaat internet bagi kelanjutan usaha mereka.

f. Kendala ketersedian koneksi internet (ISP)

Penyelenggara jasa internet merupakan perusahaan/badan yang menyelenggarakan jasa sambungan internet dan jasa lainnya yang berhubungan. Perusahaan masih ada yang meragukan akan ketersediaan ISP.

g. Tingginya biaya koneksi internet
Biaya koneksi internet di Indonesia memang masih tergolong mahal dibandingkan negara-negara lain. Sehingga bagi perusahaan-perusahaan berskala kecil maupun menengah, biaya merupakan kendala utama untuk mengakses internet.

Untuk mengetahui faktor-faktor dominan yang menyebabkan UKM belum mencoba untuk menggunakan teknologi informasi dan komunikasi, maka pada penelitian ini hal itu dapat diketahui dengan memperoleh data dari konsumen. Data tersebut diperoleh dari kuesioner yang disebar pada UKM Batik Tulis Lasem.

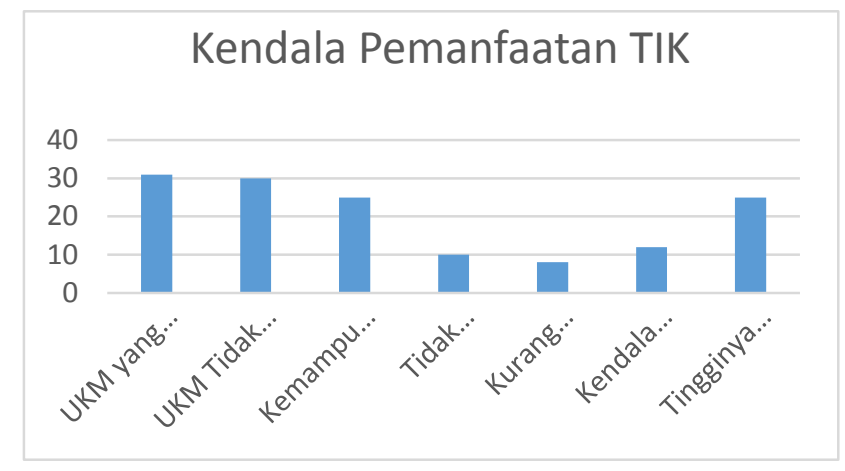

Gambar 2. Kendala Pemanfaatan TIK

Berdasarkan Gambar 2, dapat dilihat bahwa jenis kendala terbesar adalah pemilik UKM tidak banyak yang memeiliki perangkat komputer/laptop, rendahkanya kemampuan SDM dalam penguasaan teknologi serta tingginya biaya internet, serta rendahnya strategi bisnis berbasis teknologi informasi dan komunikasi. Oleh karena itu dalam penelitian ini akan dilakukan perbaikan startegi pengembangan bisnis berbasis teknologi informasi untuk menangani permasalahan minimnya kepemilikan komputer.

Selanjutnya implementasi Six Sigma kemundian menetapkan pernyataan, Tujuan, yang terdiri atas deskripsi tujuan, target kuantitatif, dan timelline atau rencana jadwal untuk menyelesaiakan Siklus DMAIC. Struktur pernyataan tujuan project implementasi Six Sigma UKM Batik Tulis Lasem sesuai prinsip SMART dapat dilihat pada Tabel 1.

\section{Tabel 1.}

Pernyataan Tujuan UKM Batik Tulis Lasem Struktur Pernyataan Tujuan UKM Batik Tulis Lasem

\begin{tabular}{|c|c|}
\hline Specific & $\begin{array}{l}\text { Meningkatkan strategi bisnis berbasis } \\
\text { TI }\end{array}$ \\
\hline Measureable & $\begin{array}{lrr}\text { Pengukuran dilakukan } & \text { terhadap } \\
\text { peningkatan strategi bisnis } & \end{array}$ \\
\hline Achieveable & $\begin{array}{l}\text { Proyek peningkatan strategi bisnis } \\
\text { dilaksanakan dengan memafaatkan } \\
\text { perangkat lain }\end{array}$ \\
\hline $\begin{array}{l}\text { Result } \\
\text { Oriented }\end{array}$ & $\begin{array}{l}\text { Mengurangi biaya } \\
\text { infrastruktur TI } 50 \%\end{array}$ \\
\hline Time-Bound & $\begin{array}{l}\text { Kegiatan peneyelesaian permasalahan } \\
\text { dengan deadline milestone } \\
\text { Define, 30 Januari } 2019 \\
\text { Measure, } 30 \text { April } 2019 \\
\text { Analyze, 15 Mei } 2019 \\
\text { Improve, 31 Juli } 2019\end{array}$ \\
\hline
\end{tabular}


Jurnal Ilmiah Ilmu Komputer Vol. 6, No. 1, Bulan April 2020 Fakultas Ilmu Komputer

Universitas AL Asyariah Mandar

\section{Control, 31 Agustus 2019}

Langkah selanjutnya pada bagian Define adalah penyusunan Piagam Proyek yaitu dengan memberikan pernyataan lingkup, tujuan, dan peserta dalam sebuah proyek. Ini memberikan penggambaran awal tentang peran dan tanggung jawab, menguraikan tujuan proyek, mengidentifikasi pemangku kepentingan utama, dan mendefinisikan wewenang. Piagam Proyek berfungsi sebagai konstitusi yang mengatur kerja proyek dan perselisihan jika ada hal yang mungkin timbul selama pelaksanaan proyek. Pada Tabel 2 menggambarkan piagam proyek untuk peningkatan pemanfaatn teknologi informasi.

Tabel 2 Piagam Proyek Pada UMK Batik Tulis Lasem

\section{Deskripsi Isu atau Masalah, Tujuan, dan Hasil Kerja Proyek}

\begin{tabular}{ll}
\hline Isu atau & Informasi pemanfaatan teknologi \\
Masalah & informasi dari UKM Batik Tulis Lasem \\
& kinerja yang belum optimal. Informasi ini \\
& diperoleh dari wawancara dan kueseioner \\
& pemilik UKM Batik Tulis.
\end{tabular}

Tujuan Untuk mengatasi masalah kurang

Proyek optimalnya pemanfaatan teknologi informasi. Kegiatan ini akan mencoba untuk mengidentifikasi akar permasalahan di balik kurang optimalnya UKM dalam pemanfaatan TI, dengan data penyelesaian dan menerapkan solusi untuk memperbaiki strategi bisnis UKM Batik Tulis Lasem.

\begin{tabular}{ll}
\hline Kasus & Keputusan bisnis penting mengenai \\
bisnis & menaikkan pemanfaaatan TI bergantung \\
& pada informasi penanganan insiden yang \\
& andal dan akurat. Kegiatan ini akan \\
& berusaha memperbaiki/memberikan \\
& masukan stratgegi layan TI yang benar \\
& yang dibutuhkan untuk mengelola bisnis \\
& pada UKM Batik Tulis Lasem di bidang \\
& teknologi informasi. Manfaat utama dari \\
& proyek ini berkaitan dengan peningkatan \\
& pemanfaatan layanan TI dalam menaikkan \\
& kualitas layanan pelanggann dan bisnis \\
& agar bisa mendukung proses bisnis dalam \\
& mencapai tujuan utama bisnis.
\end{tabular}

\begin{tabular}{llr}
\hline Sasaran & Merancang dan mengembangkan \\
& serangkaian solusi lengkap untuk \\
& mengatasi akar permasalahan di balik \\
& kurang optimalnya pemanfaatan TI. \\
& Tentukan penyebab di balik lembar kerja \\
& yang tidak diproses dan / atau diproses \\
& secara tidak benar. Tentukan penyebab di \\
& balik entri tiket permintaan layanan yang \\
& tidak diproses dan / atau diproses secara \\
tidak benar. Tentukan keseluruhan
\end{tabular}

masalah melalui analisis data, dan tes lainnya. Kembangkan solusi untuk memperbaiki proses dan memantau hasil solusi yang diimplementasikan.

Hasil yang Hasil kegiatan, Analisis Pemangku Diharapk Kepentingan, Peta Proses Pemikiran, Kritis an terhadap Karakteristik Mutu, Bagan Pareto Kesalahan dalam Manajemen Insiden Analisis Sistem Pengukuran Atribut.

\section{Ruang Lingkup Proyek}

\begin{tabular}{ll}
\hline Ruang & Kegiatan penelitian dan penyelesaian \\
lingkup & permasalahan UKM ini hanya terbatas \\
& pada pemanfatan layanan TI untuk \\
& mendukung strategi pengembangan Binsis \\
& UKM Batik Tulis Lasem.
\end{tabular}

\begin{tabular}{llr}
\hline Sumberdaya Proyek \\
\hline Tim & $\begin{array}{l}\text { Peneliti, Pemilik UKM, tim IT pada UKM, } \\
\text { Kegiatan/ } \\
\text { proyek }\end{array}$ & \\
\hline tim Pemasaran. \\
yamberda & $\begin{array}{l}\text { Pelayanan Informasi/Pemasaran pada } \\
\text { Pendukun }\end{array}$ & $\begin{array}{l}\text { UKM Batik Tulis lasem akan memberikan } \\
\text { beberapa bantuan administratif. Proyek }\end{array}$ \\
g & $\begin{array}{l}\text { yang ditinjau mungkin mendapat tugas } \\
\text { untuk membantu pengumpulan dan }\end{array}$ \\
& pengumpulan data. \\
\hline
\end{tabular}

Risiko, Kendala, dan Asumsi kegiatan

\begin{tabular}{|c|c|}
\hline Risiko & $\begin{array}{l}\text { 1. Perubahan Lingkup kegiatan perlu } \\
\text { tetap fokus pada akar permasalahan di } \\
\text { balik sumber data dan tidak } \\
\text { memperluas kegiatan ke dalam } \\
\text { pengembangan persyaratan sistem } \\
\text { untuk masalah dengan berbagai } \\
\text { aplikasi. } \\
\text { 2. Implementasi Solusi - Kegiatan ini } \\
\text { kemungkinan besar akan memerlukan } \\
\text { perubahan, menangkap dan } \\
\text { memproses data insiden. Dalam } \\
\text { beberapa kasus, Pihak UKM dapat } \\
\text { menolak dan menolak untuk } \\
\text { mengadopsi prosedur dan rekomendasi } \\
\text { baru ini. Dengan demikian, masalah } \\
\text { dengan data insiden buruk akan terus } \\
\text { berlanjut. }\end{array}$ \\
\hline Kendala & $\begin{array}{l}\text { Sumber daya yang terbatas } \\
\text { Tim penelitian/kegiatan memiliki } \\
\text { akses terbatas antar unit }\end{array}$ \\
\hline & $\begin{array}{l}\text { Kegiatan ini mengikuti pendekatan Six } \\
\text { Sigma DMAIC. Kegiatan ini } \\
\text { mengasumsikan bahwa semua } \\
\text { pemangku kepentingan/UKM akan } \\
\text { memahami dan menerima produk } \\
\text { keluaran six sigma. } \\
\text { Diharapkan pemilik }\end{array}$ \\
\hline
\end{tabular}


memberikan dukungan yang cukup untuk mendorong keberhasilan penerapan solusi yang dihasilkan dari proyek ini.

Setelah piagam proyek/kegiatan disusun, langkah berikutnya adalah menyusun Gantt chart. Tujuan dari ini adalah untuk mengidentifikasi setiap tugas yang harus diselesaikan. Hal ini kemudian digambarkan dalam bentuk yang menunjukkan kerangka waktu yang akan ditempati dalam keseluruhan kegiatan. Biasanya grafis menampilkan proses apa yang harus dilakukan sebelum tugas dapat dimulai, dan proses yang tidak dapat dimulai sampai tugas selesai. Namun, karena tugas biasanya tidak berjalan secara linier, tidak banyak panduan mengenai berapa banyak pekerjaan yang telah diselesaikan pada tugas tertentu. Tanpa terus diperbarui, sulit untuk mengetahui apakah kegiatan sesuai jadwal atau tidak. Ini hanya dapat ditemukan saat tugas tidak disampaikan pada tanggal yang ditunjukkan. Begitu ada slip waktu telah ditemukan, mengedit bagan Gantt akan dibutuhkan sehingga tugas yang bergantung pada tugas yang terlambat dijadwal ulang.

\section{Measure (Tahap Pengukuran)}

Pada tahapan ini bertujuan untuk mengukur kinerja saat ini. Adapun langkah-langkahnya adalah pengukuran, DPO (Defect per Opportunity), DPMO (Defect per Million Opportunity) dan tingkat sigma proses pada saat ini.

Pemilihan Critical to Quality (CTQ) dilakukan dengan menetapkan indikator yang digunakan untuk mengukur kinerja masing-masing CTQ.

Pengukuran baseline kinerja UKM dalam pemanfaatan teknologi informasi dilakukan dengan menggunakan parameter DPMO dan nilai sigma. Berikut perhitungan tiap keluhan (Persamaan 2.1):

a. UKM yang belum menggunakaan perangkat komputer di UKM

$$
\text { DPMO }=\frac{15}{40} \times 1.000 .000=375.736(1,87 \text { sigma })
$$

b. UKM Tidak memiliki SDM/Karyawan yang menguasi teknologi Komputer DPMO $=\frac{30}{40} \times 1.000 .000=750.000(3$ sigma $)$

c. Kemampuan SDM pemilik dalam TI Rendah DPMO $=\frac{25}{40} \times 1.000 .000=625.000(1,125$ sigma $)$

d. Tidak memilki strategi bisnis melalui internet DPMO $=\frac{10}{40} \times 1.000 .000=250.000(2,125$ sigma $)$

e. Kurang bermanfaat bagi perusahaan DPMO $=\frac{8}{40} \times 1.000 .000=200.000(2,375$ sigma $)$

f. Kendala pada kualitas internet DPMO $=\frac{12}{40} \times 1.000 .000=300.000(2$ sigma $)$

g. Tingginya biaya koneksi internet DPMO $=\frac{25}{40} \times 1.000 .000=625.000(1,125$ sigma $)$
Salah satu tujuan utama analisa adalah memahami keadaan proses. Pada aktivitas pertama dibuat daftar dengan metrik yang disarankan untuk mengevaluasi kinerja proses:

a. UKM yang belum menggunakaan perangkat komputer di UKM. Adapun uraian permasalahan yang terjadi pada UMKM adalah:

1) UKM mengandalkan perangkat gadget untuk mendukung kegiatan pemasaran.

2) UKM mengangap perangkat komputer tidak begitu penting dalam mendukung bisnis.

b. UKM Tidak memiliki SDM/Karyawan yang menguasi teknologi Komputer

1) UKM masih berfokus melakukan penjualan secara manual

2) UKM belum mementingkan pemanfaatan teknologi berbasis komputer

c. Kemampuan SDM pemilik dalam TI Rendah

1) Pemahaman pemilik UKM terhadap teknologi rendah, beberapa kegiatan yang pernah diikuti pemilik UKM berkaitan dengan pemanfaatan teknologi belum dapat diterapkan secara optimal.

2) Kurangnya motivasi untuk peningkatan pemahaman tekologi informasi, hal ini menyebabkan perkembangan bisnis menjadi stagnan.

d. Tidak memilki strategi bisnis melalui internet

1) Masih menggunakan strategi bisnis secara manual, pemanfaatan teknologi informasi untuk mendukung pemasaran menjadi kunci berkembangnya bisnis UKM Batik Tulis Lasem.

2) Perlu dilakukan pendampingan untuk optimalisasi strategi bisnis.

e. Kurang bermanfaat bagi perusahaan

1) Pemahaman yang keliru dari pemilik UKM terhadap kehadiran teknologi menjadi penghambat berkembangnya bisnis.

2) Peran aktif perguruan tinggi dan Dinas terkait menjadi kunci perkembangan UKM Batik Tulis Lasem.

f. Kendala pada kualitas internet

Jangkauan kualitas internet juga masih terbatas pad wialayah-wilayah tertentu, pemilik UKM harus memilih/menggunakan operator jaringan yang baik untuk mendukung layanan internet.

g. Tingginya biaya koneksi internet Tingginya biaya koneksi internet menjadi kendala tersendiri, solusi yang diharapkan adalah dengan pefanfaatan agdget untuk mendukung startegi pemasaran UKM Batik Tulis Lasem

\section{Tahap Analyse}


Jurnal Ilmiah Ilmu Komputer Vol. 6, No. 1, Bulan April 2020 Fakultas Ilmu Komputer

Universitas AL Asyariah Mandar

Pada Gambar 3 diagram fishbone digambarkan faktor-faktor utama permasalahan pada UKM Batik Tulis Lasem.

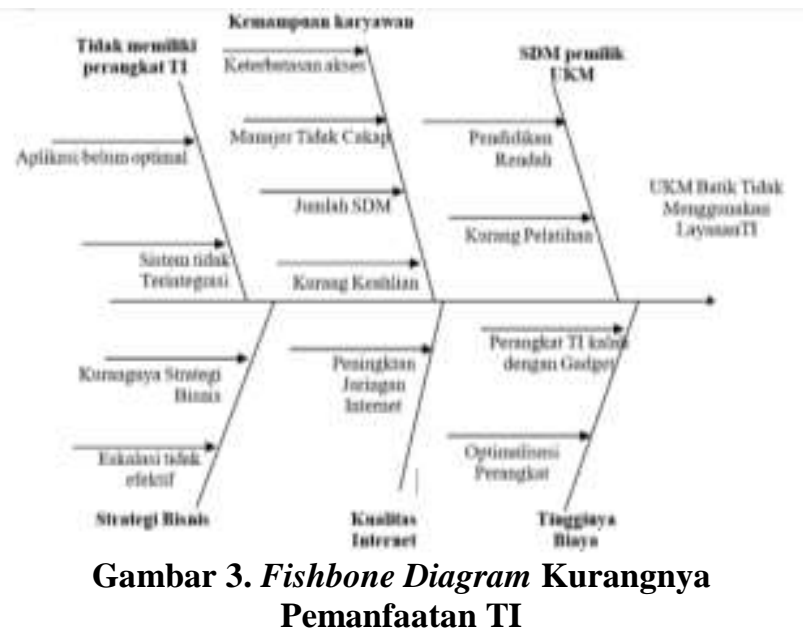

\section{Tahap Improve}

Tahap improve saat ini merupakan ususlan yang harus diterapkan UKM dalam mengembangkan bisnis UKM berbasi teknologi informasi yang melibatkan program peningkatan layanan, melibatkan penentuan bidang perbaikan, penerapan perbaikan, pelacakan dari waktu ke waktu, dan kemudian melakukan tinjauan pelaksanaan pasca untuk memastikan hasilnya. Selama tahap ini, item tindakan dikembangkan, solusi dinilai dan solusi terbaik direkomendasikan dan diterapkan.

Dengan metode six sigma, dihapus pemborosan penyebab salah satunya dengan membuat proses flow lebih sederhana, insiden langsung dicatat, kemudian operator helpdesk/operator teknologi melakukan klasifikasi kemudian prioritas insiden. Setelah mendapatkan prioritas insiden di investigasi dan di diagnosa apabila solusi ditemukan langsung dilakukan resolusi dan pemulihan lalu insiden ditutup. Tapi bila tidak ditemukan solusi maka dilakukan eskalasi lalu kembali lagi dilakukan investigasi dan diagnose, sehingga ditemuka solusi terbaik strategi pengembangan bisnis UKM Batik Tulis Lasem.

\section{Control}

Sejak fase Define, seluruh kegiatan didokumentasi dengan rapi yang merangkum seluruh hasil sampai fase Improve. Secara bertahap juga mulai disusun laporan yang akan menjadi dokumentasi seluruh kegiatan dalam perbaikan proses ini, ini menjadi penelitian lanjutan kedepannya, sehingga perkembangan UKM setelah ditemukan permasalahan dan solusi dapat dilakukan pengawasan secara baik. Untuk memastikan prosedur yang baru dilaksanakan secara konsisten, secara teratur diadakan evaluasi dan diskusi atas kinerja pelayanan pada pelanggan. Sambil berjalan, proyek percobaan dikembangkan secara bertahap sehingga semua layanan. Prosedur harus dibakukan ke dalam suatu dokumentasi yang detail dan standar sehingga benar-benar menjadi pegangan yang penting bagi setiap petugas service desk/operator TI. Termasuk didalamnya adalah diagram process flow yang setelah perbaikan menjadi lebih pendek dan lebih ramping karena adanya penyederhanaan proses sebagai efek samping dari prosedur yang lebih jelas dan sederhana. Semakin cepatnya pelayanan tentu saja mengurangi panjang antrian permintaan layanan.

\section{KESIMPULAN}

Dari pengidentifikasian faktor-faktor yang telah dilakukan pada maka dapat diketahui yang menyebabkan beberapa perusahaan tidak memanfaatkan teknologi informasi yaitu UKM yang belum menggunakan perangkat komputer di UKM, Tingginya biaya koneksi internet, Tidak memiliki tenaga ahli bidang TIK, Tidak memiliki strategi bisnis melalui internet, Kemampuan SDM pemilik dalam TI Rendah, Kurang bermanfaat bagi perusahaan, Kendala ketersedian koneksi internet (ISP). Adapun 7 keluhan tersebut yang paling banyak dikeluhkan oleh UKM adalah rendahnya kemampuan SDM pemilik dalam TI dan tingginya biaya koneksi internet. Hal itu dapat pula terlihat pada fase pengukuran, dengan tingginya biaya koneksi internet memiliki nilai sigma paling kecil dibandingkan dengan keluhan lain, yaitu sebesar 1,125 sigma. Nilai tersebut menunjukkan rendahnya kemampuan SDM pemilik dalam TI dan tingginya biaya koneksi internet harus menjadi prioritas untuk segera diperbaiki dan dicarikan solusi. Rencana perbaikan dengan memanfaatkan operator jaringan yang ada dengan memanfaatkan teknologi-teknologi terbaru, dimana koneksi internet dapat dilakukan dengan teknologi pendukung yang lebih efisien, misalnya wireless, solusi pengembangan strategi bisnis, serta peningkatan kemampuan dan pemahaman teknologi informasi pemilik UKM Batik Tulis Lasem.

\section{UCAPAN TERIMA KASIH}

1) Lembaga Penelitian dan Pengabdian pada Masyarakat STIE YPPI Rembang yang telah memberi kesempatan untuk melaksanakan penelitian ini.

2) FEDEP Kabupaten Rembang dan Dinas Perindagkop dan UMKM Kab. Rembang yang telah memberikan ijin dan data penelitian.

3) Koperasi dan Pengusaha UMKM Batik Tulis Lasem Kabupaten Rembang yang telah memberikan data dan informasi sehingga penelitian dapat terlaksana dengan baik.

\section{Daftar Pustaka}

[1] K. Desereacute and K. Thakane, "Reflecting on Information and Communication Technology (ICT) in marketing from a marketers and student perspective," African J. Bus. Manag., vol. 7, no. 31, pp. 3098-3108, 2013.

[2] A. Ollo-López and M. E. Aramendía-Muneta, "ICT impact on competitiveness, innovation and environment," Telemat. Informatics, vol. 29, no. 2, 
Universitas AL Asyariah Mandar

[3] A. Tarute and R. Gatautis, "ICT Impact on SMEs Performance," Procedia - Soc. Behav. Sci., vol. 110, pp. 1218-1225, 2014.

[4] A. A. Mahmudi and M. Tahwin, "Penentuan Produk Unggulan Daerah Menggunakan Kombinasi Metode AHP Dan Topsis (Studi Kasus Kabupaten Rembang)," J. Inform. Upgris, vol. 2, no. 2, 2016.

[5] M. Tahwin and A. A. Mahmudi, "( Probability Measurement Batik Tulis Lasem Industry Eksport Oriented )," vol. 8, no. 2, pp. 42-52, 2013.

[6] B. Nakhai and J. S. Neves, "The challenges of six sigma in improving service quality," Int. J. Qual. Reliab. Manag., vol. 26, no. 7, pp. 663-684, 2009.

[7] D. A. Prameswara, Mustafid, and A. Prahutama, "Metode Servqual-Six Sigma Untuk Peningkatan Kualitas Pelayanan Publik (Studi Kasus Di Kantor Kecamatan Kedungbanteng, Purwokerto)," J. Gaussian, vol. 3, no. 4, pp. 625-634, 2014.

[8] G. Pakki, R. Soenoko, and P. Budi Santoso, "Usulan Penerapan Metode Six Sigma Untuk Meningkatkan Kualitas Klongsong (Studi Kasus Industri Senjata)," J. Eng. Manag. Industial Syst., vol. 2, no. 1, pp. 10-18, 2014.

[9] UU No. 20 Tahun 2008, "UU No. 20 Tahun 2008," UU No. 20 Tahun 2008, no. 1, pp. 1-31, 2008.

[10] Sandriana, Hakim, and Saleh, "Strategi Pengembangan Produk Unggulan Daerah Berbasis Klaster di Kota Malang," Reformasi, vol. 5, no. 1, pp. 89-100, 2015. 